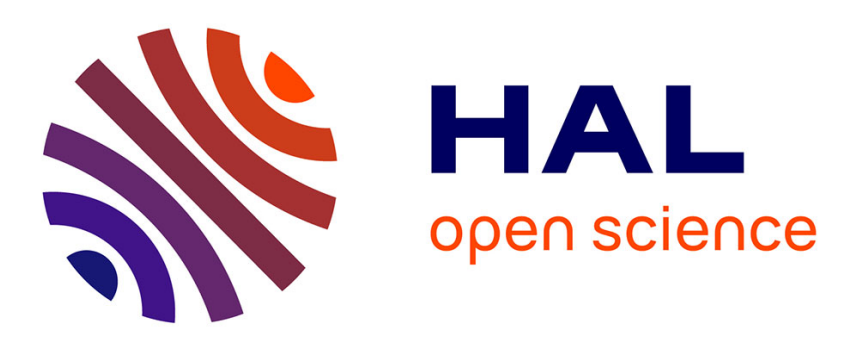

\title{
Glacier ice in rock glaciers: a case study in the Vanoise Massif, Northern French Alps
}

S Monnier, Christian Camerlynck, Fayçal Rejiba, C Kinnard, Py Galibert

\section{To cite this version:}

S Monnier, Christian Camerlynck, Fayçal Rejiba, C Kinnard, Py Galibert. Glacier ice in rock glaciers: a case study in the Vanoise Massif, Northern French Alps. The Cryosphere Discussions, 2011, 5 (6), pp.3597-3626. 10.5194/tcd-5-3597-2011 . hal-01740094

\section{HAL Id: hal-01740094}

\section{https://hal-normandie-univ.archives-ouvertes.fr/hal-01740094}

Submitted on 31 May 2021

HAL is a multi-disciplinary open access archive for the deposit and dissemination of scientific research documents, whether they are published or not. The documents may come from teaching and research institutions in France or abroad, or from public or private research centers.
L'archive ouverte pluridisciplinaire $\mathbf{H A L}$, est destinée au dépôt et à la diffusion de documents scientifiques de niveau recherche, publiés ou non, émanant des établissements d'enseignement et de recherche français ou étrangers, des laboratoires publics ou privés. 


\section{Glacier ice in rock glaciers: a case study in the Vanoise Massif, Northern French Alps}

S. Monnier ${ }^{1,}$, , C. Camerlynck $^{2}$, F. Rejiba ${ }^{2}$, C. Kinnard ${ }^{1}$, and P.-Y. Galibert ${ }^{2}$

${ }^{1}$ Centro de Estudios Avanzados en Zonas Áridas (CEAZA), Campus Andrés Bello, Casilla 554, Raúl Bitrán s/n, La Serena, Chile

${ }^{2}$ UMR 7619 Sisyphe, Université Pierre et Marie Curie-Paris 6, 4 place Jussieu, 75252 Paris Cedex 05, France

"formerly at: UMR 8591 Laboratoire de Géographie Physique (LGP), CNRS-Bellevue Campus, 1 place Aristide Briand, 92195 Meudon Cedex, France

Received: 2 November 2011 - Accepted: 13 December 2011 - Published: 21 December 2011 Correspondence to: S. Monnier (sebastien.monnier@ceaza.cl)

Published by Copernicus Publications on behalf of the European Geosciences Union.
TCD

5, 3597-3626, 2011

Glacier ice in rock glaciers

S. Monnier et al.

Title Page

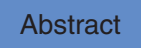

Introduction

Conclusions

References

Tables

Figures

14

I

4

Back

Close

Full Screen / Esc

Printer-friendly Version

Interactive Discussion 


\section{Abstract}

We investigated the Sachette rock glacier, Vanoise Massif, Northern French Alps, using former equilibrium line altitude reconstruction from glacial deposits, aerial photograph analysis, and ground-penetrating radar (GPR). The rock glacier is a young (probably

$5<6000 \mathrm{yr}$ ) and active landform. The GPR survey consisted of two CMP measurements and four constant-offset profiles. From CMP measurements, the radar wave velocity in exposed shallow massive ice is $0.165-0.17 \mathrm{~m} \mathrm{~ns}^{-1}$. The constant-offset GPR data was processed and analysed in order to reconstruct the stratigraphy and model the radar wave velocity in two dimensions. The integration of the morphology, the velocity models, and the stratigraphy emphasized, in the upper half of the rock glacier, the good correspondence between high radar wave velocities $\left(>0.15-0.16 \mathrm{~m} \mathrm{~ns}^{-1}\right)$ and reflectors having a dipping-syncline structure, typical of true glaciers. Consequently, the rock glacier structure is described as being constituted of a glacial massive ice core embedded into diamictons. Our study of the Sachette rock glacier highlights possible 15 significance of rock glaciers and interactions between glacier and permafrost in alpine environments.

\section{Introduction}

Rock glaciers are remarkable and intensively studied landforms of high altitude and high latitude mountains. Typically, rock glaciers are hundreds to thousands of meters long tongues with a striking ridge-and-furrow surface morphology, and well defined, steep margins, which contain or - when fossil - contained underground ice, and when active - displace a few $\mathrm{cm}$ to a few $\mathrm{m} \mathrm{yr}^{-1}$ due to the gravitational deformation of the ice-rock mixture. In most current works, active and inactive rock glaciers are considered as the major expression of the alpine mountain permafrost (Haeberli et al., 2006; Berthling, 2011). Over the last decades, they have received an increasing interest as major components of the cryosphere, and, more specifically, as potentially

5, 3597-3626, 2011

Glacier ice in rock glaciers

S. Monnier et al.

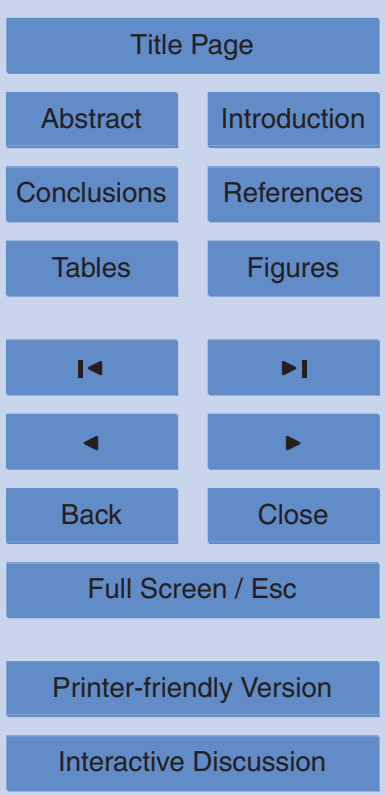

Interactive Discussion 
unstable surfaces in a changing climate context (e.g., Roer et al., 2008) or as solid water reservoirs in semi-arid to arid areas (e.g., Azócar and Brenning, 2010). The internal structure of rock glaciers has been observed only on rare occasions either from natural exposures or from boreholes (see Haeberli et al., 2006). Therefore, since the inaugural 5 work by Wahrhaftig and Cox (1959), the internal structure of rock glaciers has raised questions and controversies that regularly gave rise to synthesis or epistemological works (e.g., Whalley and Martin, 1992; Berthling, 2011). The main issues involved in the debates have been the category and origin of the inner ice (glacial vs. permafrost), as well as the inclusion, or not, of morphogically analogous landforms with an exten10 sive glacier ice core (called, e.g., ice-cored rock glaciers by Potter, 1972, or glacierderived rock glaciers by Humlum, 1996) in the rock glacier terminology better than in the debris-covered glacier realm. Even if recent definitions (Berthling, 2011, p. 6: "[rock glaciers are] the visible expression of cumulative deformation by long-term creep of ice/debris mixture under permafrost conditions") allow for the development of rock glaciers from glaciers as long as permafrost conditions exist, the existence of creeping features mainly cored with massive ice in permafrost environments is still a latent issue. Works giving complete, indisputable evidences of such landforms are rare, notably in mid-latitude mountain belts (Humlum, 1996, 2000; Fukui et al., 2008). Beyond the potential epistemological challenge, the identification of ice-cored rock glaciers has important implications in terms of environmental changes by highlighting the relay processes that may occur in the transition between glacial and periglacial worlds. In order to improve the knowledge of the herein depicted issue, we present in this paper the case study of the Sachette rock glacier, Vanoise Massif, Northern French Alps, for which a glacial origin was hypothesized on the basis of the morphology and natural exposures of its internal structure. In order to test further this hypothesis, and hence to go further in the understanding of the significance of rock glaciers, we used former glacier ELA calculations, contemporary photogrammetric measurements of rock glacier dynamics, and sophisticated ground-penetrating radar (GPR) analysis. The use of GPR is crucial in our work. Over the last decade, this geophysical method has been shown

\section{Glacier ice in rock glaciers}

S. Monnier et al.

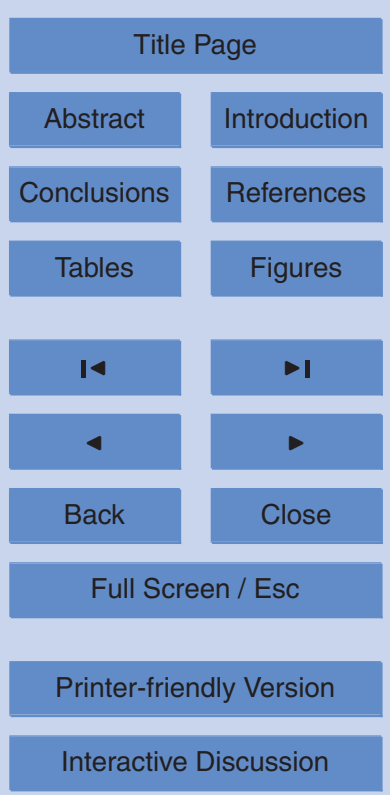

Interactive Discussion 
to be an efficient tool for revealing the stratigraphy of rock glaciers (see the synthesis by Degenhardt, 2009). However, so-called multi-offset, or multifold, GPR measurements used in several contexts for modelling the radar wave velocity and revealing subsurface materials (see, e.g., Bradford et al., 2009; Brown et al., 2009) are, for physical, 5 logistical, and financial reasons, generally impossible to perform on difficult and poorly accessible sites like rock glaciers. Whereas it could thus seem vain to hope to highlight their internal materials using basic (common mid-point and constant-offset) GPR surveys, we present here a method based on the distribution of the radar wave velocity that allows obtaining a detailed view of the rock glacier internal structure.

\section{Physical setting and morphology of the Sachette rock glacier}

The Sachette rock glacier is located in the north-eastern part of the Vanoise Massif (Fig. 1), approximately $40 \mathrm{~km}$ south to the Mt Blanc $(4810 \mathrm{~m})$, in the so-called Vallon de la Sachette, a small valley whose geomorphology is dominated by periglacial landforms, with glacial heritages in grass-covered areas (Fig. 2). The rock glacier is

15 located between 2640 and $2480 \mathrm{~m}$ on the northern face of a 2900-3000 m-culminating calcareous and quartzitic crest. At the station of Bourg-St-Maurice $(865 \mathrm{~m})$, the regional climate is characterized by a mean annual air temperature of $9.4^{\circ} \mathrm{C}$ and a mean total annual rainfall of $985 \mathrm{~mm}$. On the basis of the these data and using a linear gradient of $-0.6{ }^{\circ} \mathrm{C} / 100 \mathrm{~m}$, the $0{ }^{\circ} \mathrm{C}$ and $-2{ }^{\circ} \mathrm{C}$ isotherms are located at elevations of 2432 and $2765 \mathrm{~m}$, respectively (Monnier, 2006). The Sachette rock glacier is quite short $(\sim 350 \mathrm{~m})$ but has a pristine and bulged appearance, exhibiting archetypal ridge-andfurrow surface features, and margins up to several tens of metres high. The petrography of the blocks on the surface is mixed (quartzites and limestones). The rock glacier morphology (Fig. 2) is divided into four main parts. (1) The upper part (2640-2600 m) appears as a gently-sloping extension of the upper scree slopes $(2780-2650 \mathrm{~m})$. The morphology is dominated by the presence of two $10-15 \mathrm{~m}$ high, rounded lateral crests that connect clearly to a net of concentric and arcuate ridges on the central part of the

Glacier ice in rock glaciers

S. Monnier et al.

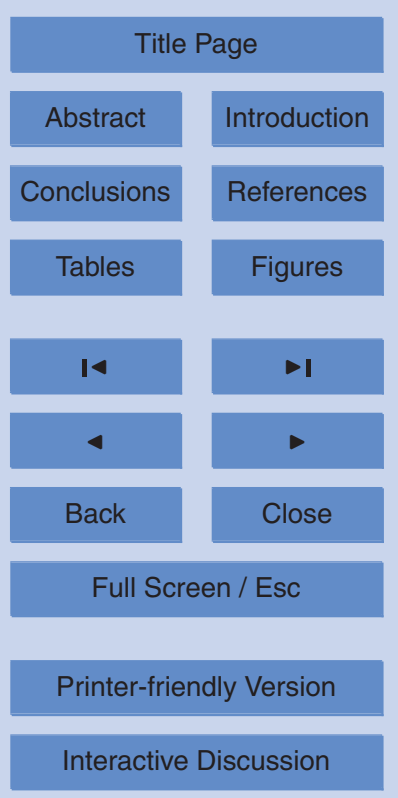


rock glacier. These two crests appear embedded into morphologically and sedimentologically distinct debris units. Between the two crests, the morphology exhibits signs of downwasting (inward facing ramps along the crest sides, elliptic depression). (2) In continuation of the upper part, the central part of the rock glacier $(2600-2570 \mathrm{~m})$ has 5 an overall low slope $\left(<10^{\circ}\right)$ and is delimited downward by a $5-8 \mathrm{~m}$ high scarp. On the central part, the surface is composed of blocks with $0.2-0.3 \mathrm{~m}$ axis length on average. The morphology is a remarkable succession of arcuate, concentric, and narrow ridges, whose height ranges between 1 and $2 \mathrm{~m}$ and width is typically $5-7 \mathrm{~m}$, separated by narrow furrows. The ridges are more arcuate in the eastern half of the rock glacier. 10 (3) The lower part $(2570-2500 \mathrm{~m})$ appears overlapped by the central part. There, the blocks on the surface are larger ( $>0.6 \mathrm{~m}$ axis), covered by lichens, and the ridges are fewer and larger (width $>10 \mathrm{~m}$ ). To the west and north, the front of the rock glacier appears as a tall (more than $40 \mathrm{~m}$ ), continuous and steep $\left(40^{\circ}\right)$ slope. To the east, the front appears as a cascading series of small scarps that overlaps (4) a morphologi15 cally decayed, grass-covered rock glacier unit $(2500-2480 \mathrm{~m})$. To the east, the rock glacier faces an old, grass-covered but well identifiable frontal push moraine. The push moraine is covered on it western flank by a gross accumulation of boulders probably originating from a large rock fall. The same type of material size is encountered to the west of the rock glacier where subdued permafrost creeping-like features are visible 20 (Fig. 2).

The rock glacier is considered as a contemporary permafrost feature. The modelling studies of the potential permafrost distribution in the French Alps (Boeckli et al., 2011) have included the Sachette rock glacier within the permafrost areas. In the field, the monitoring of the ground surface temperature (GST) at one ridge-furrow site using thermistors with $\mathrm{a} \pm 0.1^{\circ} \mathrm{C}$ accuracy has shown thermal regimes typical of permafrost active layer, with the first decimetres of the ground being frozen between October and at least May, and differential behaviours according to location (Fig. 3). The furrow is systematically colder than the ridge in summer and especially during the fall, with possible very intense cooling in the latter period. Inversely, in winter, the ridge is colder,

Glacier ice in rock glaciers

S. Monnier et al.

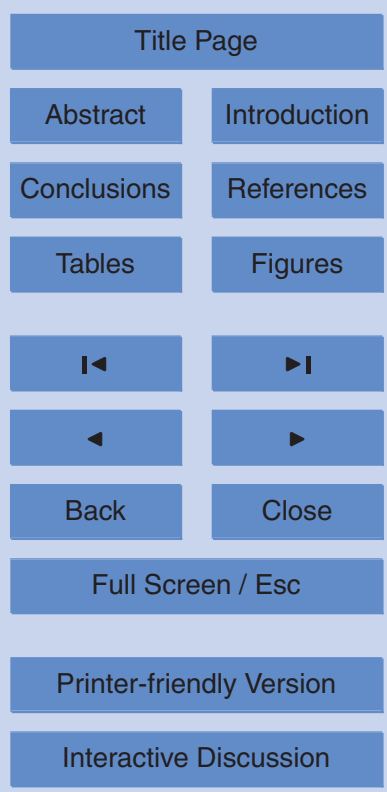


since snow fully fills the furrows and may be windblown from the top of the ridges, as it was observed during field trips. Furthermore, repeated temperature measurements in springs at the north-western part of the front gave values close to $0^{\circ} \mathrm{C}$. The nature and distribution of ground ice in the rock glacier may be complex and vary according 5 to longitudinal changes in surface morphology. For example, indications about the internal structure of the upper rock glacier were given during the late summer of 2003 and 2004, after all late lying snow banks had disappeared, when nine $\sim 1 \mathrm{~m}$ thick massive ice exposures were observed in marginal, longitudinal furrows between 2615 and $2625 \mathrm{~m}$ (Fig. 4).

10 The geomorphologic description of the rock glacier thus gives rise to the two following hypotheses. (1) As the surface architecture appears complex (with, especially, embedding and overlapping features), the rock glacier has formed in several phases. (2) A massive ice core is present at least in the upper part of the rock glacier.

\section{Methods}

\section{3.1 Calculation of former glacial equilibrium line altitude (ELA)}

In order to estimate the formation time of the Sachette rock glacier, the elevation of the frontal push moraine near the rock glacier (Fig. 2) was used as a proxy. As the rock glacier is an intact landform, its development must have occurred (at least in its main part) after the deposition of the push moraine. We used the elevation of the push moraine to calculate the corresponding former glacial ELA. We used the socalled toe-to-headwall altitude ratio (THAR). The THAR method assumes that the ELA lies at a fixed proportion of the elevation range of a former glacier; THAR of 0.350.40 are generally described for cirque and valley glaciers (Meierding, 1982; Benn and Lehmkuhl, 2000; Munroe and Mickelson, 2002). The THAR is given by the formula:

${ }_{25} \mathrm{THAR}=\frac{\mathrm{ELA}-z_{\mathrm{G}, \min }}{z_{\mathrm{G}, \max }-z_{\mathrm{G}, \min }}$

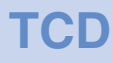

5, 3597-3626, 2011

\section{Glacier ice in rock} glaciers

\section{S. Monnier et al.}

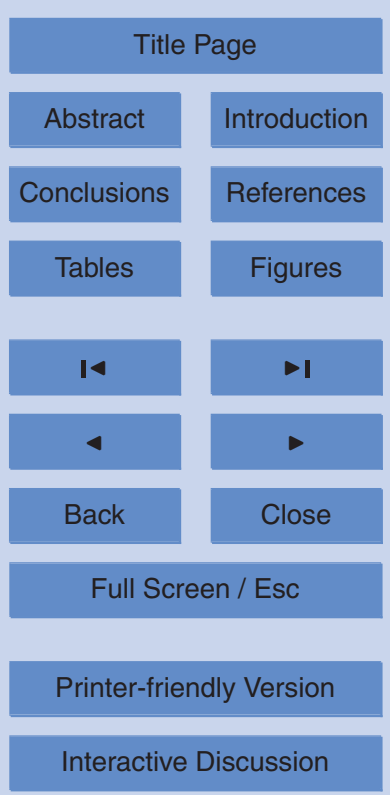


where $z_{G \text {,min }}$ is the minimum elevation of the former glacier, given by the elevation of the frontal moraine, and $z_{\mathrm{G} \text {,max }}$ is the maximum elevation of the former glacier. The latter is generally determined using the base of the upper rock walls, as done in this study. The THAR is operator-dependent. According to tests realized on existing glaciers by 5 Monnier (2006), the best THAR in the Vanoise Massif is 0.35. The ELA of the former glacier corresponding to the Sachette push-moraine was calculated and compared with the ELAs at the Ruitor Glacier, $18 \mathrm{~km}$ NNE to the Sachette rock glacier, that are related with absolute ages (Porter and Orombelli, 1982; Burga, 1995; Le Roy Ladurie, 2003). Admittedly, the THAR method does not refer directly to the glacier mass balance 10 and is influenced by the determination of the maximal elevation of the former glacier. Nonetheless, it was considered as a good opportunity to obtain local chronological information.

\subsection{Photogrammetric measurements}

Two orthophotos provided by the IGN (Institut Géographique National, France) for the 15 years 2006 and 2009 were analyzed and compared. On the basis of 28 common points chosen over stable topography, the average positional error between the two images was estimated to be $1.3 \mathrm{~m}$ (standard deviation of $0.9 \mathrm{~m}$ ), without any preferential direction. Fifty-five boulders, well visible on the rock glacier surface, were mapped at the pixel resolution $(0.5 \mathrm{~m})$ in both images, with the aim of measuring horizontal dis20 placements. From boulder displacements, horizontal velocity vectors were computed and interpolated over the rock glacier surface using kriging techniques (Isaaks and Srivastava, 1989; Davis, 2002). Punctual displacements and interpolated vectors corresponding to velocity less than the positioning incertitude $(1.8 \mathrm{~m}$ for the $2006-2009$ period, i.e., $0.6 \mathrm{~m} \mathrm{yr}^{-1}$ ) were not represented in the final results.

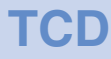

5, 3597-3626, 2011

Glacier ice in rock glaciers

S. Monnier et al.

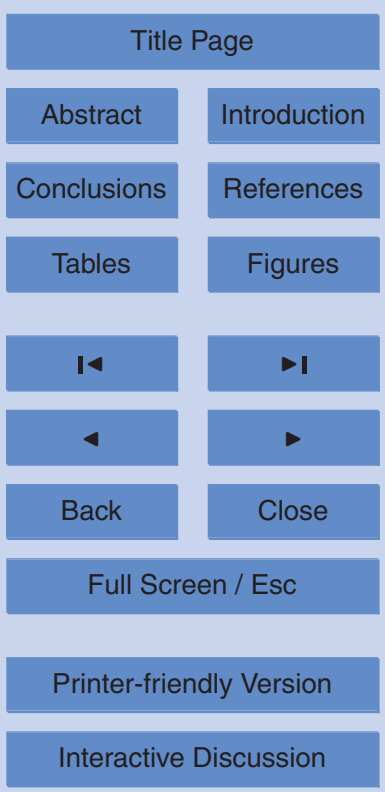




\subsection{Ground-penetrating radar (GPR) data acquisition}

Ground-penetrating radar (GPR) measurements were performed on the Sachette rock glacier (Fig. 2) using a pulseEKKO 100 system (Sensors and Software Inc.) and $50 \mathrm{MHz}$ antennae. The survey was conducted at the beginning of April 2008, in late

5 winter conditions, in order to benefit from the presence of a residual snow cover, which helped in traversing the surface and in crossing the frontal and lateral margins. Common mid-point (CMP) measurements were performed on the upper part of the rock glacier, where massive ice exposures where observed. Four constant-offset profiles were realized in longitudinal (LP\#1 and LP\#2, $430 \mathrm{~m}$ and $400 \mathrm{~m}$ long, respectively) and transversal (TP\#1 and TP\#2, both $200 \mathrm{~m}$ long) directions. The antennae were separated by $2 \mathrm{~m}$, oriented perpendicular to the survey direction, and traces were recorded every $50 \mathrm{~cm}$. Each trace was the result of 16 stacks in order to increase the signal to noise ratio. Basic and common data processing included file editing and merging, and removing of the lowest frequency component ("dewow") of the GPR traces. Elevation data were acquired along the GPR transects from differential GPS (DGPS).

\subsection{GPR data processing}

The advanced processing of the GPR data aimed at both estimating the radar wave velocity distribution in two dimensions, and reconstructing the stratigraphy through the fundamental step of migration. Let us recall that the radar wave velocity $(v)$ is related to the relative dielectric permittivity $(\varepsilon)$ by the relation:

$v=\frac{c}{\sqrt{\varepsilon}}$

where $c$ is the velocity of light in a vacuum $\left(0.299 \mathrm{mns}^{-1}\right)$; the relative permittivity depends primarily on the volumetric water content (Daniels, 2004). In this study, we first analyzed the CMP data following common procedures (Eisen et al., 2002; An-

nan, 2003) in order to obtain punctual determinations of the radar wave velocity in

Glacier ice in rock glaciers

S. Monnier et al.

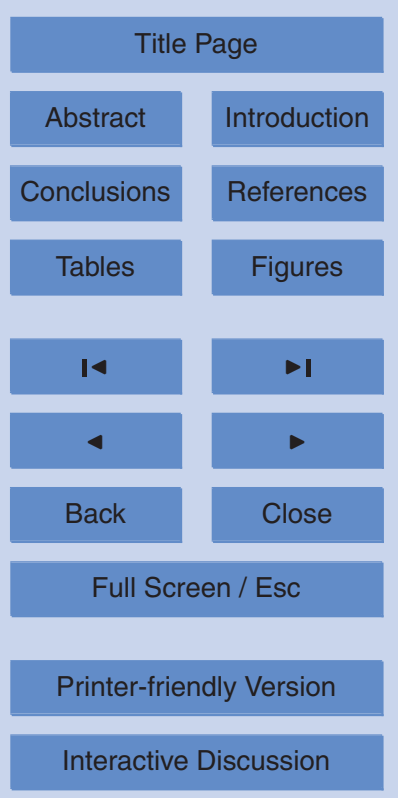

Interactive Discussion 
the shallow structure of the upper part of the rock glacier. Then, we aimed at obtaining two-dimensional (2-D) models of the radar wave velocity using the constant-offset data. This was possible with the two longitudinal profiles where numerous diffraction hyperbolae were present in the raw data. On the opposite the transversal profiles 5 did not exhibit a sufficient number of hyperbolae. We used the common hyperbolafitting method provided by GPR software for local determinations of the velocity. The diffraction velocity measured by matching a theoretical hyperbola along the tails of an observed hyperbola can be considered as a good approximation of the RMS velocity $\left(v_{\text {rms }}\right)$ and thus be used for the calculation of the "true" interval velocity $\left(v_{n}\right)$ using the 10 classical Dix' formula (Dix, 1955):

$v_{n}=\sqrt{\frac{v_{\mathrm{rms}, n}^{2} t_{n}-v_{\mathrm{rms}, n-1}^{2} t_{n-1}}{t_{n}-t_{n-1}}}$

where $v_{\mathrm{rms}, n}$ and $v_{\mathrm{rms}, n-1}$ are the RMS velocities for reflectors located at two-way traveltimes of $t_{n}$ and $t_{n-1}$, respectively. There is no doubt that the hyperbola-fitting method can be difficult and prone to errors, especially in complexly stratified structures where interferences between out-of-plane diffractions, and between diffractions and true reflectors, are frequent and may lead to erroneous velocity determinations. The method requires ignoring ambiguous hyperbolae while identifying a sufficiently large number of points with adequate spatial distribution. With these conditions met, we used an analysis based on the coupling between the reconstruction of the stratigraphy and the 2-D modelling of the interval velocity $\left(v_{n}\right)$. We especially used a regular grid with rectangular cells of dimensions $12.5 \mathrm{~m} \times 50 \mathrm{~ns}$ to integrate the diffraction velocity determinations and to calculate values of the interval velocity using Eq. (3). The dimension of the cells was fine enough to capture and take into account the main stratigraphic divisions revealed in the topographically migrated (Lehmann and Green, 2000) and

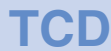

5, 3597-3626, 2011

Glacier ice in rock glaciers

S. Monnier et al.

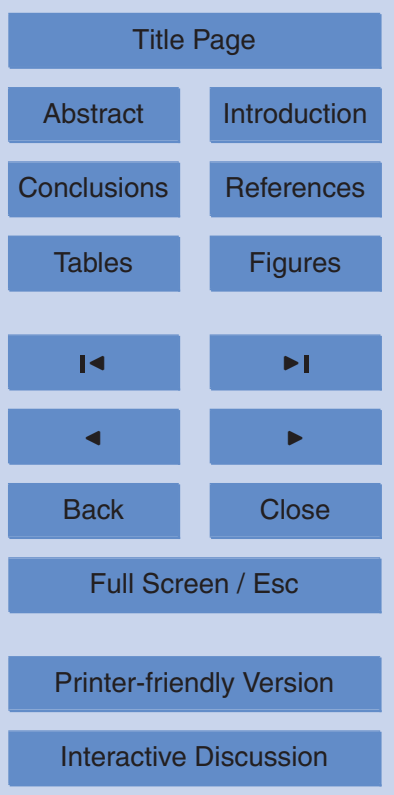


SEC (spreading for exponential compensation)-gained profiles. The interval slowness ${ }^{1}$ (inverse of the velocity) was finally interpolated in 2-D using kriging (Isaaks and Srivastava, 1989; Davis, 2002), and subsequently converted to interval velocity. This 2-D interval velocity field was then used to transform both the 2-D velocity model and 5 the migrated profile from position-TWT domain into position-depth domain. The final interpretation of the internal structure along the two longitudinal profiles was based on the superimposition of the velocity model onto the migrated profile. Moreover, the transversal profiles were migrated using topographic migration.

\section{Results}

\subsection{Former ELA calculation}

Using a THAR of 0.35 , the former ELA corresponding to the frontal push moraine located near the rock glacier is $2560 \mathrm{~m}$. At the nearby Ruitor Glacier, two glacial phases have been well identified (Porter and Orombelli, 1982; Burga, 1995). The oldest one corresponds to the La Thuile frontal moraines $(1480 \mathrm{~m})$. Using the AAR method, Porter 5 and Orombelli (1982) calculated the ELA of the corresponding former glacier to be $2350 \mathrm{~m}$ and determined the glacier advance to be younger than the ${ }^{14} \mathrm{C}$ moraine age of 8395 cal. BP ( beginning of the Holocene climatic optimum in the area according to Burga, 1995), probably Late Glacial. Using the THAR method with a 0.35 value, Monnier (2006) calculated the ELA for the same glacier to be $2180 \mathrm{~m}$. The second glacial phase occurred during the Little Ice Age (LIA), when the Ruitor Glacier advanced to an elevation of 2300 m (Burga, 1995; Le Roy Ladurie, 2003) which using a THAR of 0.35 corresponds to an ELA of $2715 \mathrm{~m}$. According to these data and considering the relict appearance (grass-covered, topographically depressed) of the push moraine, the

\footnotetext{
${ }^{1}$ An important requirement for kriging is that the variable be additive (Journel and Huijbregts, 1978; Armstrong, 1998), which is the case for the slowness (Wyllie et al., 1958).
}

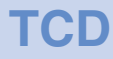

5, 3597-3626, 2011

\section{Glacier ice in rock glaciers}

S. Monnier et al.

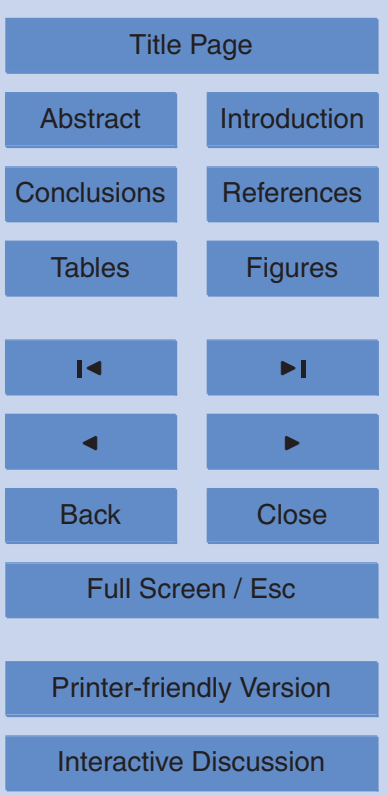


latter can neither be attributed to the Late Glacial nor to the LIA. It must, therefore, be related to one of the glacial phases younger than the climatic optimum (8300-5000 BP according to Burga, 1995) that were not so far from the LIA in amplitude (Patzelt, 1974; Le Roy Ladurie, 2003). Finally the rock glacier, apart from the decayed unit (Fig. 2), is 5 younger than the push moraine; it is considered to be no more than a few (5000-6000) thousands of years old.

\subsection{Horizontal displacements on the surface}

Most of the rock glacier surface showed significant displacements $\left(0.6-1.2 \mathrm{~m} \mathrm{yr}^{-1}\right)$ between 2006 and 2009 (Fig. 5). The rock glacier can thus be considered an active land10 form. Also, most movement vectors point downslope, as expected from gravitational deformation, and follow the main landform axis, from south to north. The displacements are smaller in the upper part and larger in the central-eastern part of the rock glacier, where the morphology - stronger planar curvature and downward amplification of the surface ridges - does suggest larger strain rates. In the upper part of the rock glacier, 15 between the two main lateral ridges, inward displacements are observed, which tend to confirm the occurrence of downwasting processes.

\subsection{Punctual determination of the radar wave velocity in massive ice}

Both CMP analyses exhibit well defined profiles in the velocity vs. TWT domain (Fig. 6). The first high amplitude zone between 150 and 200 ns allowed determining radar wave velocities in the buried massive ice to be $0.165-0.17 \mathrm{~m} \mathrm{~ns}^{-1}$. This is consistent with values previously reported in the literature for buried ice (Brandt et al., 2007: 0.15$0.17 \mathrm{~m} \mathrm{~ns}^{-1}$; Fukui et al., 2008: $0.17 \mathrm{~m} \mathrm{~ns}^{-1}$ ).

\subsection{Two-dimensional (2-D) modelling of the radar wave velocity}

The two final 2-D velocity models (Fig. 7) exhibit strong contrasts, with values ranging 25 between 0.03 and $0.18 \mathrm{~m} \mathrm{~ns}^{-1}$ in the LP\#1 profile and between 0.03 and $0.19 \mathrm{~m} \mathrm{~ns}^{-1}$ 3607
5, 3597-3626, 2011

Glacier ice in rock glaciers

S. Monnier et al.

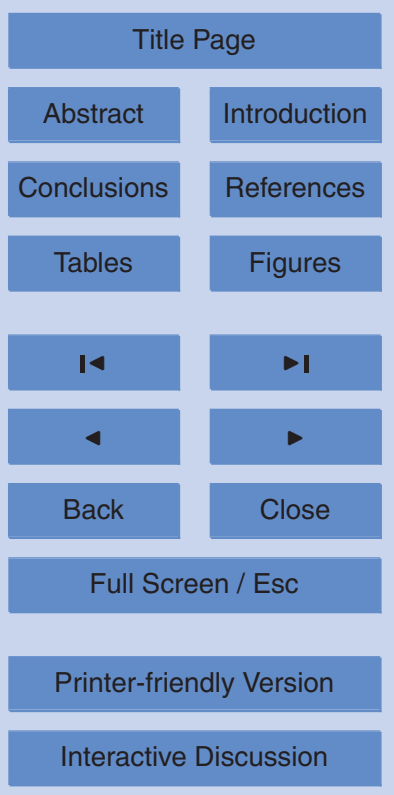

Interactive Discussion 
in the LP\#2 profile. The most striking feature of the models is the predominance of areas with high velocities $\left(>0.15-0.16 \mathrm{~m} \mathrm{~ns}^{-1}\right)$. Near-surface values may sometimes be over-estimated due to the influence of a locally thicker snow cover, which affected the original velocity determination along hyperbolae. This was the case along the front

5 of the rock glacier, in the distal part of LP\#1, where thick snow cover was encountered during the survey and appears clearly in the stratigraphic reconstruction (see further), and in the upper part of LP\#2, where very high values $\left(0.18-0.19 \mathrm{~m} \mathrm{~ns}^{-1}\right)$ were encountered. Areas with low velocities $\left(<0.08-0.09 \mathrm{~m} \mathrm{~ns}^{-1}\right)$ are encountered as thin fringes in the lower and deeper part of the profiles. The lowest values $\left(0.03-0.04 \mathrm{~m} \mathrm{~ns}^{-1}\right)$ 10 could result from local extrapolation artefacts at the margins of the interpolation domain and/or from small errors in the local determinations of the velocity along hyperbolae, which propagate to the calculation and interpolation of the interval velocity. The velocity models for the two profiles differ to some extent, which may reflect differences in the density of diffraction hyperbolae in the original data, or genuine spatial variations in the 15 internal structure and composition of the rock glacier: indeed the stratigraphy between the two longitudinal profiles appears quite different, especially in the upper part of the rock glacier (see next paragraph and Fig. 8).

\subsection{Integrated representation of the internal structure along GPR longitudinal profiles}

20 An optimal representation of the rock glacier internal structure along its longitudinal axis (LP\#1 and LP\#2) is given by combining the morphological divisions, the 2-D velocity models and the reconstructed stratigraphy (Fig. 8). The graphical results are presented without topographic correction to allow better visualization of all reflectors. Clear, basal bounding reflectors appear prominently in the upper sections of LP\#1 and LP\#2 and in the terminal part of LP\#1. Beneath these basal bounding reflectors, the signal amplitude is considerably weakened; additionally, the velocity decreases, which could however be explained by the lack of diffractions in the original data. Interpreting these basal bounding reflectors to represent the actual interface between

Glacier ice in rock glaciers

S. Monnier et al.

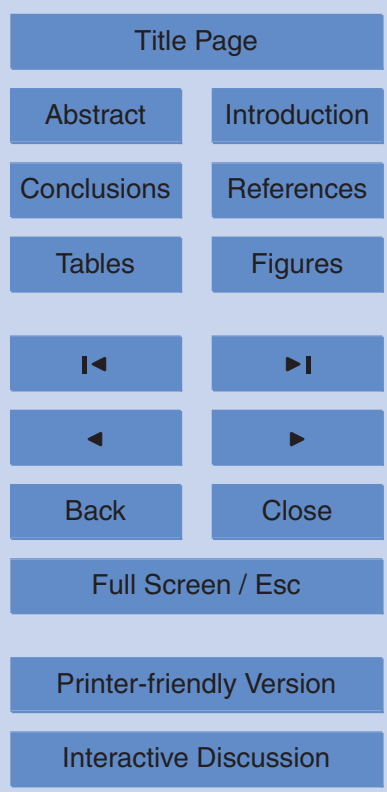


the rock glacier and the bedrock, or a separate deposit, the corresponding rock glacier thickness varies from less than $10 \mathrm{~m}$ in its uppermost section, to $40 \mathrm{~m}$ in its centre. A striking characteristic of our results is the correspondence, in the upper and central parts of the rock glacier, between reflectors with a dipping-syncline structure and ar5 eas of high velocities $\left(>0.15-0.16 \mathrm{~m} \mathrm{~ns}^{-1}\right)$. This dipping-syncline structure constitutes the most prominent type of reflector pattern seen in the rock glacier. The examination of LP\#1 gives the most comprehensive illustration: parallel to, or onlap-based on the basal bounding reflector, series of reflectors sink down-rock glacier before rapidly turning into up-rock glacier dipping events. The thickness of such structures reaches 10 35-40 $\mathrm{m}$ in the case of LP\#1. In LP\#2, they are thinner and overlap, below $20 \mathrm{~m}$, a pattern of more chaotic and undulating reflectors, which reflects spatially variable internal stratigraphy. Whereas dipping-syncline structures mostly match up with zones of high velocities, the velocity is seen to decrease significantly in the deepest parts of both LP\#1 and LP\#2, reaching values of less than $0.10 \mathrm{~m} \mathrm{~ns}^{-1}$. In the lower part of the rock 15 glacier, the velocity decreases to values between 0.11 and $0.15 \mathrm{~m} \mathrm{~ns}^{-1}$. There, the pattern of reflectors is less distinct, which could be explained by larger debris size, which would create too many diffraction points to allow a clear structure to appear in the GPR profiles.

Both LP\#1 and LP\#2 profiles exhibit a shallow (3-6 m deep, with a subtle increase 20 in depth downslope), undulating reflector (SU reflector), subparallel to the surface, and visible along quite the entire profile length. At first sight, this reflector could be interpreted to represent the base of the snow cover present at the site during the GPR survey. However, the amount of snow on the rock glacier was in fact restricted, with the top of the ridges being free of snow, while the top of the undulations in the shallow reflector is generally at least 3-4 m deep. Furthermore, the true rock glacier-snow interface is well visible in the front section and appears distinct from the SU reflector. Hence the SU reflector must represent a near-surface stratigraphic boundary separating two media with considerably different electromagnetic properties.

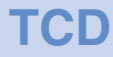

5, 3597-3626, 2011

\section{Glacier ice in rock glaciers}

S. Monnier et al.

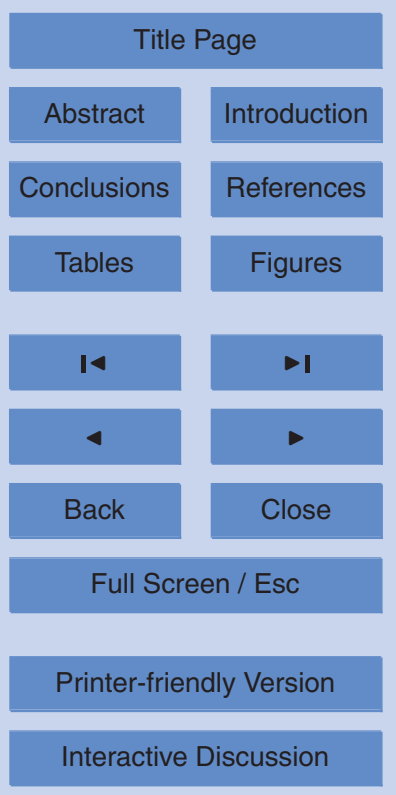




\subsection{Transverse GPR profiles}

The two transverse profiles (TP\#1 and TP\#2, Fig. 9) provide clear transversal views of the internal structure in the upper rock glacier. Syncline structures are evident in the central part of the profiles. Next to and below these syncline structures, the reflector 5 patterns are less distinct, and evocate the structure encountered in the lower part of the longitudinal profiles. Basal bounding reflectors can be delineated between 10 and $25 \mathrm{~m}$ depth in TP\#1 and between 20 and $35 \mathrm{~m}$ depth in TP\#2.

\section{Discussion}

\subsection{Structure of the Sachette rock glacier}

10 The originality of the GPR results presented in this study resides in: (i) the concurrence, in the upper and central part of the rock glacier, of high radar wave velocities, with (ii) reflectors having a dipping-syncline structure; and (iii) the occurrence of a shallow, undulating (SU) interface. Unambiguously, the high modelled velocities $(>0.15-$ $0.16 \mathrm{~m} \mathrm{~ns}^{-1}$ ) constitute a strong evidence for, to say the least, high ice contents. The

15 type of dipping-syncline structure evidenced here are very different from reflector structures previously highlighted by GPR surveys in other rock glaciers of the Vanoise Massif (Monnier et al., 2008, 2009) and elsewhere in the Alps (Lehmann and Green, 2000; Hausmann et al., 2007), where the reflectors generally tend to follow the surface topography in undulating-toplapping sequences. They are, in contrast, very similar to GPR structures corresponding to debris-rich layers formed by thrusting movement in true glaciers (Murray and Booth, 2010) or in rock glaciers with evident debris-covered massive ice core (Fukui et al., 2008). As Fukui et al. (2008) did in the case of the Tumbledown Norte rock glacier (Antarctica Peninsula), we can compare the dippingsyncline structures observed in the Sachette rock glacier with the so-called "nested spoons" foliated structures formed by the deformation of pre-existing inhomogeneities,

5, 3597-3626, 2011

Glacier ice in rock glaciers

S. Monnier et al.

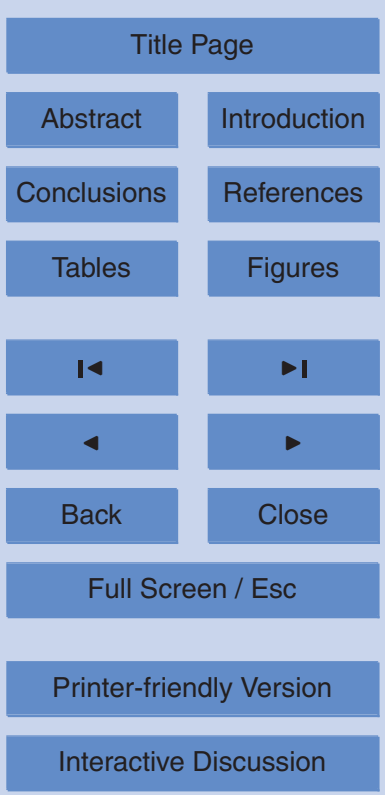

Interactive Discussion 
such as debris layers, during the flow of ice in true glaciers (Hooke and Hudleston, 1978; Cuffey and Paterson, 2010). Finally, the SU reflector may represent: (i) the lower limit of the permafrost active layer, unfrozen during the GPR surveys (thermal interpretation); (ii) the boundary between a top blocky layer with low or even null ice content 5 and the deeper ice-rich layers (fabric interpretation). These represent two contrasting interpretations. In 2008, the temperature monitoring of the active layer unfortunately stopped on 17 March, two weeks before the GPR survey. On that date the temperature in the first meter was $-5^{\circ} \mathrm{C}$, still well below zero. Therefore, at the date of the survey, the active layer was very probably still frozen. Furthermore, in the lowermost 10 segment of LP\#1 (Fig. 8), the SU reflector can be more than $10 \mathrm{~m}$ deep, which resembles more the limit between an ice-rich structure and the apron of debris accumulating at the front, rather than a deep, unfrozen active layer. The second interpretation (ii) is thus favoured. The generally high velocities encountered within the top blocky layer are likely due to the presence of air and snow, and, at such a fine scale, the 2-D velocity 15 models cannot pick up velocity variations that could be induced by this shallow interface. The SU reflector disappears in the uppermost section of the rock glacier, where the thickness of the top blocky layer reduces and is no more detectable with the GPR configuration employed.

Our analyses lead us to conclude that the structure of the Sachette rock glacier 20 in its upper and central part is mainly constituted of glacial-inherited, debris-covered, massive ice core with numerous synclinally-disposed debris layers. The ice core is up to $30 \mathrm{~m}$ thick, with a significant downslope increase in thickness. The decrease in radar wave velocity identified at the base of the dipping-syncline structures must relate to an increase in water content; as morphological and dynamical evidences (down25 wasting features and inward displacements of the rock glacier surface) for ice melting are present in the upper part of the rock glacier, flowing water along the rock glacier floor may even take place. This would mean that permafrost conditions do not exist in the deeper part of the ice-cored rock glacier, which is in accordance with the permafrost distribution that Humlum (1996) depicted in his glacier-derived rock glacier

Glacier ice in rock glaciers

S. Monnier et al.

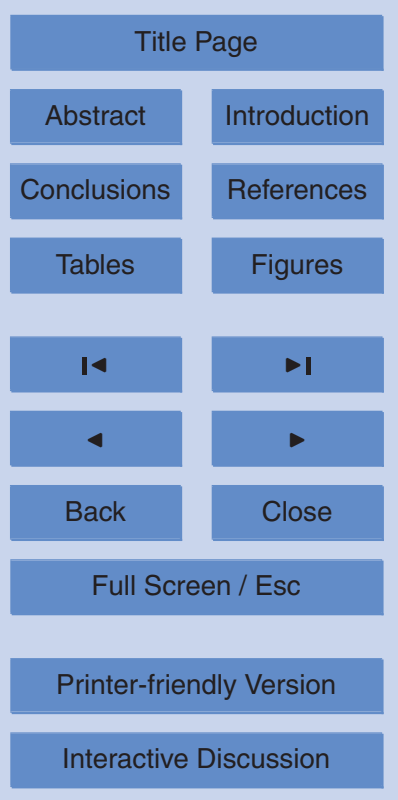


model. Going down the rock glacier, the debris layers density increases, as suggested by a higher density of reflectors in the transition zone between the central and lower parts of the rock glacier. Below (upper part of LP\#2, TP\#1 and 2) and beside the ice core (TP\#1 and 2), the changes in the reflector patterns (undulating, chaotic, or less 5 distinct) must be related to the decrease in velocity and to the multi-units morphology of the rock glacier: the ice core of the rock glacier overlaps, and is embedded into, debris units (diamictons) potentially frozen near the surface.

The lower part of the rock glacier differs from the upper and central part by its morphology, more subdued reflector structures, and lower though still moderate to high

10 radar wave velocities $\left(0.11-0.15 \mathrm{~m} \mathrm{~ns}^{-1}\right)$. In accordance with the architecture of the upper parts, the structure of the lower part is then thought to be made of an ice-rock mixture. The domed and pristine appearance of the surface, the noticeable surface displacements, and the radar wave velocity (Daniels, 2004) are all compatible with permafrost materials, and the prolongation of the subparallel-near-surface interface is an 15 argument to infer a high ice content. The presence of internal, isolated bounding reflector suggests that thrusting mechanisms may have occurred. Below 20-30 m depths, the strong decrease in velocity suggests that moist or even water-saturated materials may be encountered.

\subsection{Genesis of the Sachette rock glacier}

20 As hypothesized in the description of the morphology, and according to our interpretations, the Sachette rock glacier has developed during at least three phases corresponding to, successively and respectively, the morphologically decayed part, the lower part, and the associated upper and central part. The three development stages took place during the last 5000-6000 yr. The accumulation of glacial ice and debris, the conserva25 tion of glacial ice remnants in permafrost conditions, along with periglacial/paraglacial burying, and the formation of periglacial ice from infiltration and refreezing of snow and rain into diamictons are the major mechanisms implied in the genesis of the rock glacier. Arguments lack for dating and describing the exact deposition mechanisms for

Glacier ice in rock glaciers

S. Monnier et al.

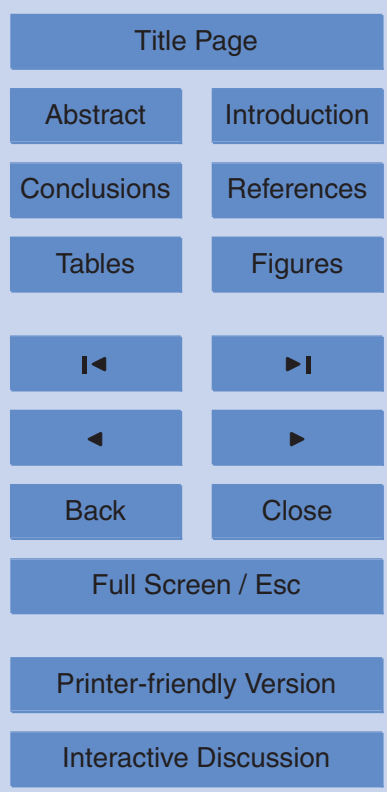


the decayed and lower morphological units. Conversely, the upper and central parts of the rock glacier are clearly related to at least one former glacier advance onto and into the diamicton deposits, the glacier ice being subsequently buried and preserved in permafrost conditions. The ice exposed at the upper end of the rock glacier is probably

5 inherited from the LIA. The burying of the ice may have occurred following sudden and large rock falls, as suggested by the ruiniform appearance of the rock walls at the site. The diamictons in the lower part of the rock glacier constituted a topographic obstacle, resulting in compression both in the sediments and in the upper glacier. The scenario explains, in the upper and central part of the rock glacier, the marked curvature of the 10 synclinally-disposed layers in the ice and the very dense net of concentric, arcuate ridges on the surface. The arcuate ridges were either created by deformation of the blocky layer or from up-lifting of englacial debris along emergent thrust planes in the glacier. The latter hypothesis would require, however, finer scale GPR investigations to be validated. As the computed displacements show, the rock glacier as a whole has been moving forward, with a downslope amplification of compressive stresses and ridge morphology, especially at the contact between the lower and central part of the rock glacier. Currently, the ice core is melting in the upper part where the top blocky layer is thinner, resulting in downwasting movements and associated surface morphology, and running meltwater below the permafrost layer, at the base of the rock glacier.

\section{Conclusions}

We have investigated the Sachette rock glacier, Northern French Alps, using former ELA calculation from adjacent moraines, photogrammetric measurements, and advanced processing of GPR data. We analysed the GPR data with the aims of modelling the distribution of the radar wave velocity, reconstructing the geometry of reflectors in the rock glacier and, ultimately, understanding its internal structure. Beyond methodological challenge, the insight we generated brings advance in the knowledge of the geomorphological significance and origin of rock glaciers. Indeed, this study has

Glacier ice in rock glaciers

S. Monnier et al.
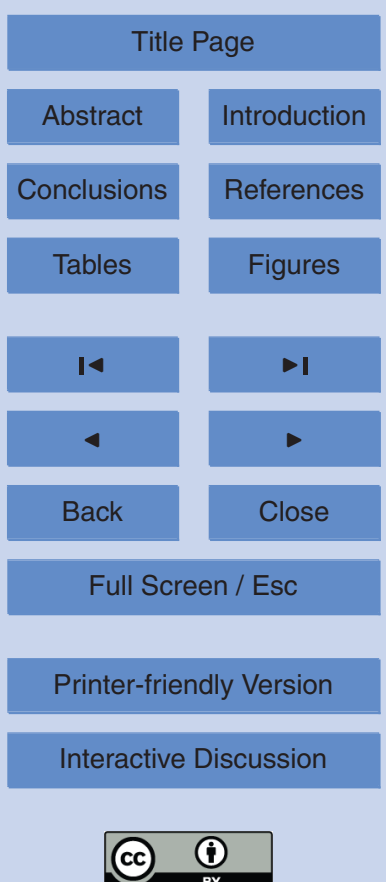
provided the following major conclusions:

1. The rock glacier is an active landform, showing significant surface displacements of $0.6-1.2 \mathrm{~m} \mathrm{yr}^{-1}$.

2. The upper rock glacier is composed of a massive ice core, as evidenced by ice exposures observed at the surface, and high radar wave velocities (0.15$0.18 \mathrm{~m} \mathrm{~ns}^{-1}$ ) below the surface, as measured and modelled from both CMP and constant offset GPR surveys.

3. The internal stratigraphy of the rock glacier is composed of numerous synclinally disposed reflectors, analogous to those seen in true glaciers, and are thus interpreted to be debris-rich thrust planes; the ice core is thus thought to be of glacial origin.

The rock glacier formed during one, or several, alternating phases of glacier advance and permafrost development over the last few thousands of years.

Acknowledgements. The field work was financially supported by both the UMR 8591 LGP and 15 the UMR 7619 Sisyphe of the CNRS, France. We thank the Tignes ski station for the use of the ski lifts. The Slope Security Service of Tignes, directed by Arnaud Trinquier, provided helpful assistance for transporting material to the study site. Moreover, the authors would like to thank sincerely Stéphane Rutard who provided physical and safety supervising as mountain guide, as well as a friendly presence during all the field trip.

\section{References}

Annan, A. P.: Ground Penetrating Radar principles, Procedures and Applications, Mississauga, Sensors and Software Inc., 2003.

Armstrong, M.: Basic Linear Geostatistics, Springer, Berlin, 166 pp., 1998.

Azócar, G. F. and Brenning A.: Hydrological and geomorphological significance of rock glaciers in the dry Andes, Chile (27 $\left.-33^{\circ} \mathrm{S}\right)$, Permafrost Periglac., 21, 42-53, 2010.

\section{Glacier ice in rock glaciers}

S. Monnier et al.

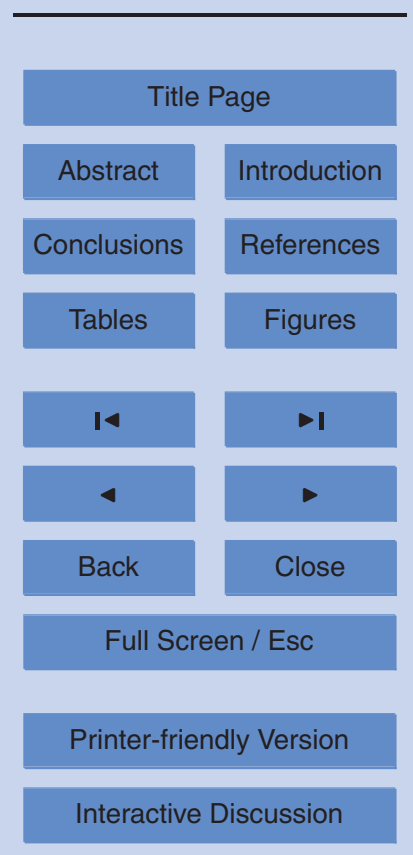


Benn, D. I. and Lehmkuhl, F.: Mass balance and equilibrium-line altitudes of glaciers in highmountain environments, Quatern. Int., 65/66, 15-29, 2000.

Berthling, I.: Beyond confusion: rock glaciers as cryo-conditioned landforms, Geomorphology, 131, 98-106, 2011.

5 Boeckli, L., Brenning, A., Gruber, S., and Noetzli, J.: A statistical permafrost distribution model for the European Alps, The Cryosphere Discuss., 5, 1419-1459, doi:10.5194/tcd-5-14192011, 2011.

Bradford, J. H., Nichols, J., Mikesell, T. D., and Harper, J. T.: Continuous profiles of electromagnetic wave velocity and water content in glaciers: an example from Bench Glacier, Alaska,

10 USA, Ann. Glaciol., 50, 1-9, 2009.

Brandt, O., Langley, K., Kohler, J., and Hamran, S.-E.: Detection of buried ice and sediment layers in permafrost using multi-frequency Ground Penetrating Radar: a case examination in Svalbard, Remote Sens. Environ., 111, 212-227, 2007.

Brown, J., Nichols, J., Steinbronn, L., and Bradford, J.: Improved GPR interpretation through 15 resolution of lateral velocity heterogeneity: example from an archaeological site investigation, J. Appl. Geophys., 68, 3-8, 2009.

Burga, C. A.: Végétation et paléoclimatologie de l'Holocène moyen d'une ancienne tourbière située au front du Glacier du Ruitor, 2510 m (Vallée d'Aoste, Italie), Rev. Géogr. Alp., 83, 9-16, 1995.

Cuffey, K. M. and Paterson, W. S. B.: The Physics of Glaciers, 4th edn., Elsevier, Oxford, 715 pp., 2010.

Daniels, D. J.: Ground Penetrating Radar - 2nd edn., The Institution of Electrical Engineers, Stevenage, 726 pp., 2004.

Davis, J. C.: Statistics and Data Analysis in Geology, 3rd edn., John Wiley and Sons, New York, 25656 pp., 2002.

Degenhardt Jr., J. J.: Development of tongue-shaped and multilobate rock glaciers in alpine environments - interpretations from ground penetrating radar surveys, Geomorphology, 109, 94-107, 2009.

Dix, C. H.: Seismic velocities from surface measurements, Geophysics, 20, 68-86, 1955.

30 Eisen, O., Nixdorf, U., Wihelms, F., and Miller, H.: Electromagnetic wave speed in polar ice: validation of the common-midpoint technique with high-resolution dielectric profiling and gamma-density measurements, Ann. Glaciol., 34, 150-156, 2002.

Fukui, K., Sone, T., Strelin, J. A., Torielli, C. A., Mori, J., and Fujii, Y.: Dynamics and GPR

\section{Glacier ice in rock} glaciers

S. Monnier et al.

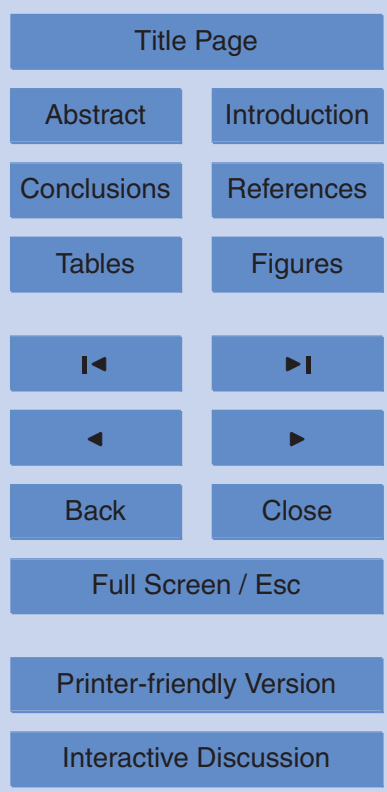


stratigraphy of a polar rock glacier on James Ross Island, Antarctic Peninsula, J. Glaciol., 54, 445-451, 2008.

Haeberli, W., Hallet, B., Arenson, L., Elconin, R., Humlum, O., Kääb, A., Kauffmann, V., Ladanyi, B., Matsuoka, M., Springman, S., and Vonder Mühll, D.: Permafrost creep and rock glacier dynamics, Permafrost Periglac., 17, 189-214, 2006.

Hausmann, H., Krainer, K., Brückl, E., and Mostler, W.: Internal structure and ice content of Reichenkar rock glacier (Stubai Alps, Austria) assessed by geophysical investigations, Permafrost Periglac., 18, 351-367, 2007

Humlum, O.: Origin of rock glaciers: observations from Mellemfjord, Disko Island, Central West Greenland, Permafrost Periglac., 7, 361-380, 1996.

Hooke, R. L. and Hudleston, P. J.: Origin of foliation in glaciers, J. Glaciol., 20, 285-299, 1978.

Isaaks, E. H. and Srivastava, R. M.: An Introduction to Applied Geostatistics, Oxford University Press, New York, 592 pp., 1989.

Journel, A. G. and Huijbregts, C. J.: Mining Geostatistics, Academic Press, London, New York, 15600 pp., 1978.

Lehmann, F. and Green, A.: Topographic migration of georadar data: implications for acquisition and processing, Geophysics, 65, 836-848, 2000.

Le Roy Ladurie, E.: Histoire du Climat depuis I'an mil, Flammarion, Paris, 541 pp., 2003.

Meierding, T. C.: Late Pleistocene glacial equilibrium-line altitudes in the Colorado Front Range: a comparison of methods, Quaternary Res., 18, 289-310, 1982.

Monnier, S.: Les glaciers-rocheux, objets géographiques, Analyse spatiale multiscalaire et investigations environnementales, Applications aux Alpes de Vanoise, Ph.D. Thesis, University Paris 12-Val de Marne, 337 pp., 2006.

Monnier, S., Camerlynck, C., and Rejiba, F.: Ground-penetrating radar survey and stratigraphic interpretation of the Plan du Lac rock glaciers, Northern French Alps, Permafrost Periglac., 19, 19-30, 2008.

Monnier, S., Camerlynck, C., and Rejiba, F.: Ground-penetrating radar surveys on rock glaciers in the Vanoise Massif (Northern French Alps): methodological issues, Géomorphologie, 2, 129-140, 2009.

30 Munroe, J. S. and Mickelson, D. M.: Last glacial maximum equilibrium-line altitudes and paleoclimate, Northern Uinta Mountains, Utah, USA, J. Glaciol., 48, 257-266, 2002.

Murray, T. and Booth, A. D.: Imaging glacial sediment inclusions in 3-D using groundpenetrating radar at Kongsvegen, Svalbard, J. Quaternary Sci., 25, 754-761, 2010.

\section{Glacier ice in rock} glaciers

S. Monnier et al.

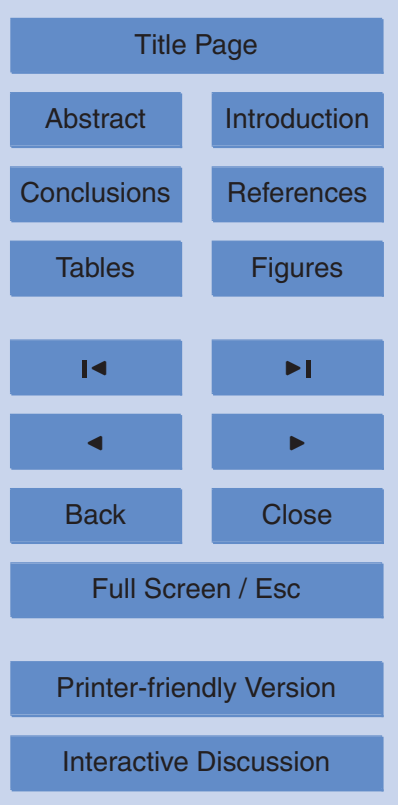


Patzelt, G.: Holocene Variations of Glaciers in the Alps, Colloques Internationaux du CNRS, 219, 51-59, 1974.

Porter, S. C. and Orombelli, G.: Late-glacial ice advances in the Western Italian Alps, Boreas, 11, 125-140, 1982.

5 Potter Jr., N.: Ice-cored rock glacier, Galena Creek, Northern Absaroka Mountains, Wyoming, Geol. Soc. Am. Bull., 83, 3025-3058, 1972.

Roer, I., Haeberli, W., Avian, M., Kaufmann, V., Delaloye, R., Lambiel, C., and Kääb, A.: Observations and considerations on destabilizing active rock glaciers in the European Alps, in: Ninth International Conference on Permafrost, edited by: Kane, D. L. and Hinkel, K. M., vol. 2, Institute of Northern Engineering, University of Alaska, Fairbanks, 1505-1510, 2008.

Sensors and Software: EKKO_View Enhanced and EKKO_View Deluxe user's guide, Sensors and Software Inc., Mississauga, Canada, 132 pp., 2003.

Wahrhaftig, C. and Cox, A.: Rock glaciers in the Alaska Range, Geol. Soc. Am. Bull., 70, 383-436, 1959.

Whalley, W. B. and Martin, H. E.: Rock glaciers: II Models and mechanisms, Prog. Phys. Geog., 16, 127-186, 1992.

Wyllie, M. R. J., Gregory, A. R., and Gardner, G. H. F.: An experimental investigation of factors affecting wave velocities in porous media, Geophysics, 23, 459-493, 1958.

\section{5, 3597-3626, 2011}

\section{Glacier ice in rock} glaciers

S. Monnier et al.

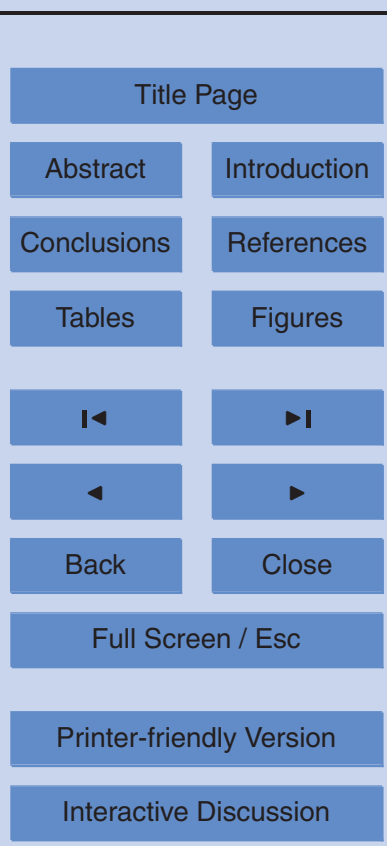




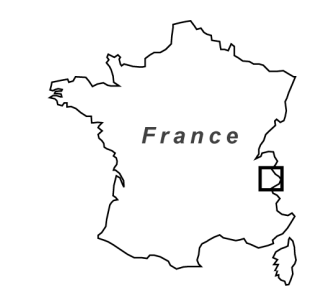

Mt Blanc (4810 m)

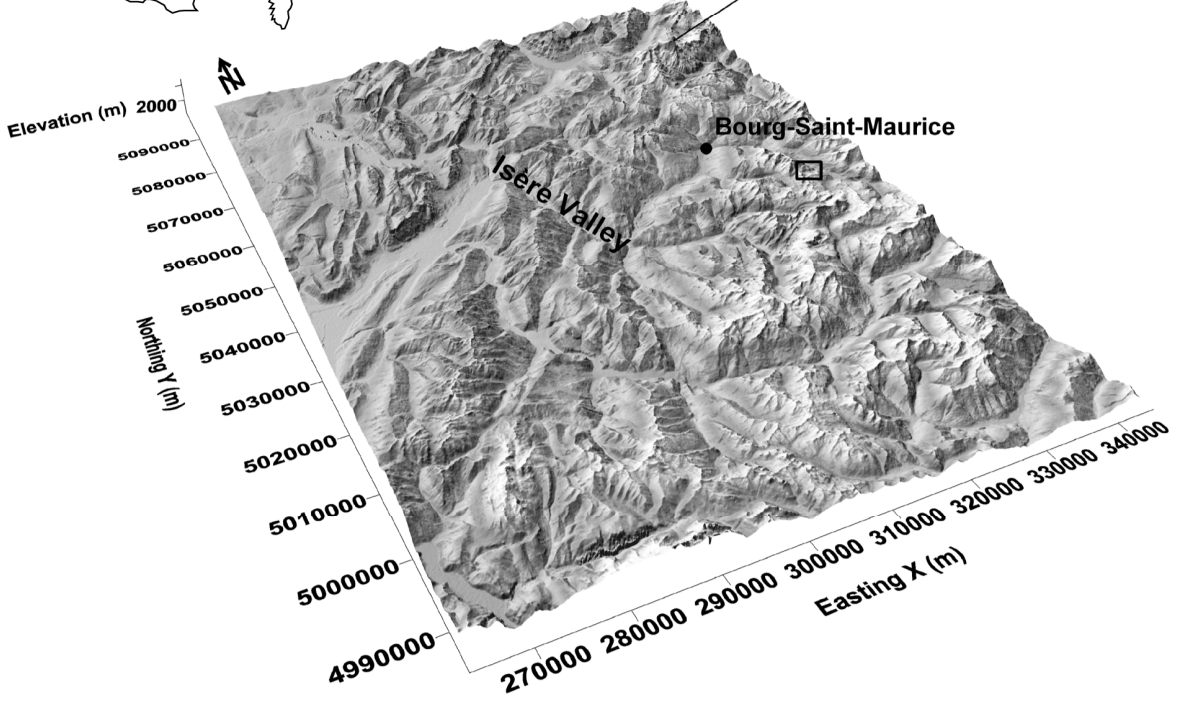

Fig. 1. Location sketch of the Sachette rock glacier. The coordinates system, as for all subsequent figures, is UTM32-WGS84.

\section{TCD}

5, 3597-3626, 2011

Glacier ice in rock glaciers

S. Monnier et al.

Title Page

\begin{tabular}{|c|c|}
\hline Abstract & Introduction \\
\hline Conclusions & References \\
\hline Tables & Figures \\
\hline & \\
\hline I4 & - I \\
\hline 4 & \\
\hline Back & Close \\
\hline Full Screen / Esc \\
\hline
\end{tabular}

Printer-friendly Version

Interactive Discussion 
a)

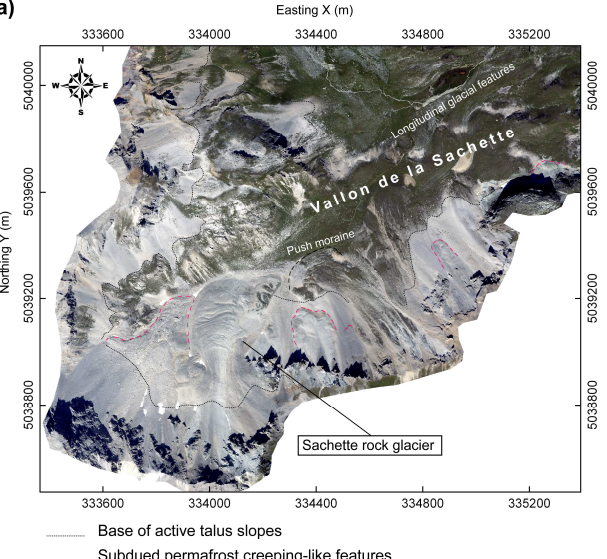

TCD

5, 3597-3626, 2011

\section{Glacier ice in rock glaciers}

\section{S. Monnier et al.}

b) Easting $X(m)$
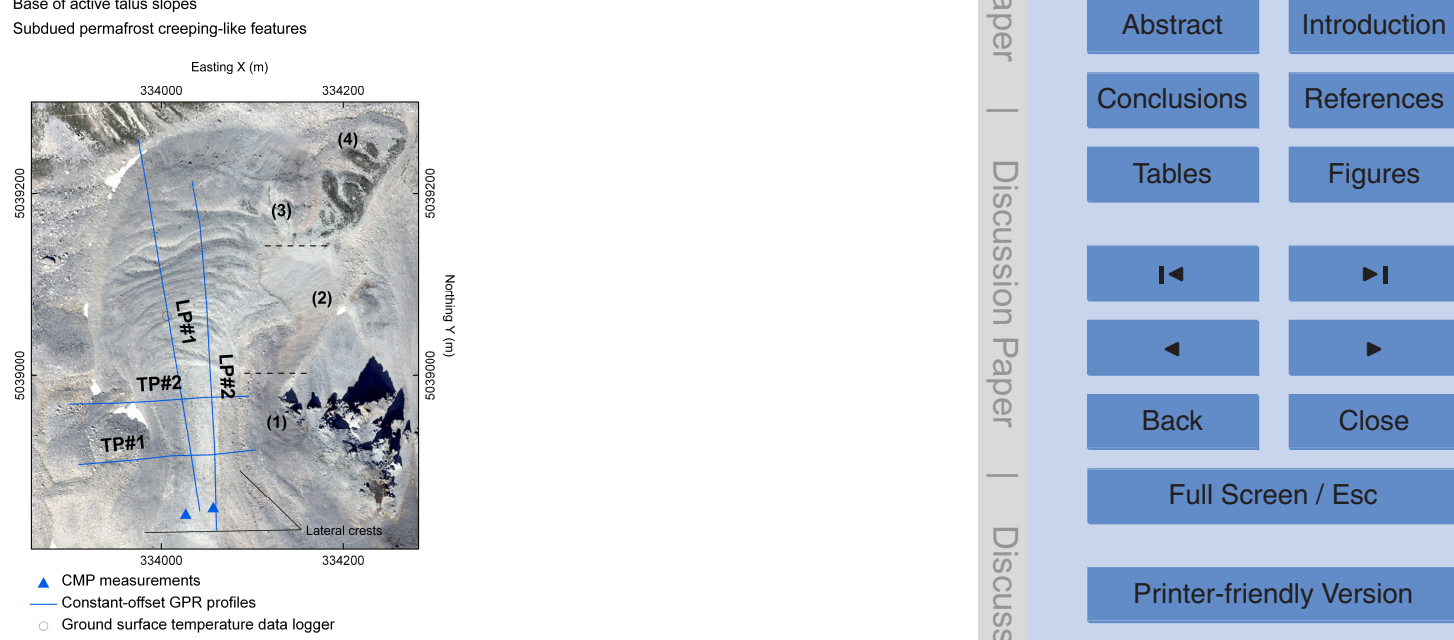

Printer-friendly Version

Fig. 2. Simplified geomorphological map of the Vallon de la Sachette (a) and focus view on the Sachette rock glacier surface (b). The numbers (1), (2), (3), and (4) on (b) refers to the morphological parts of the rock glacier (see text for details). 


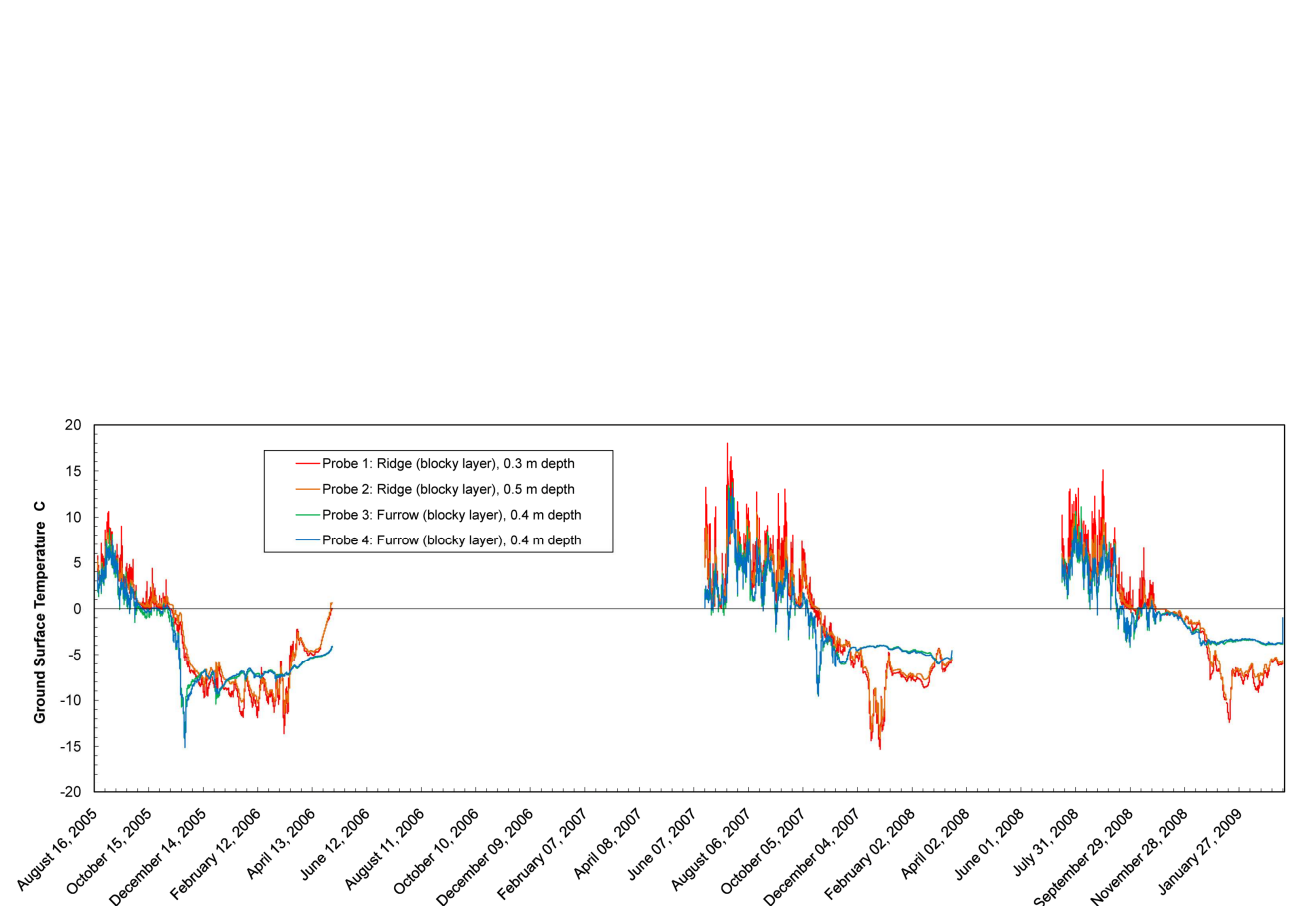

Fig. 3. Monitoring of the ground surface temperature (GST) at the Sachette rock glacier. See Fig. 2 for location of the datalogger.

\section{Glacier ice in rock} glaciers

\section{S. Monnier et al.}

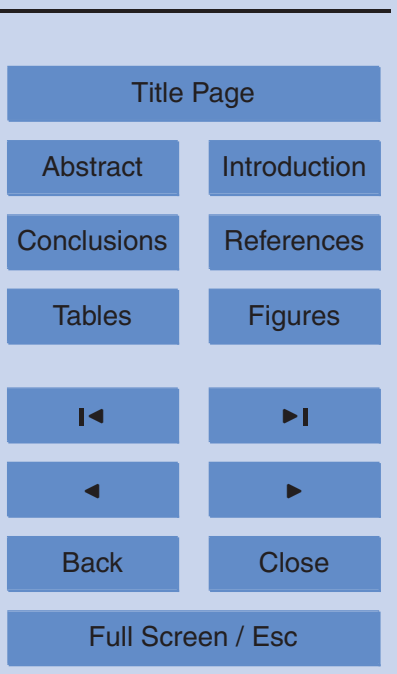

Printer-friendly Version

Interactive Discussion

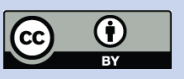




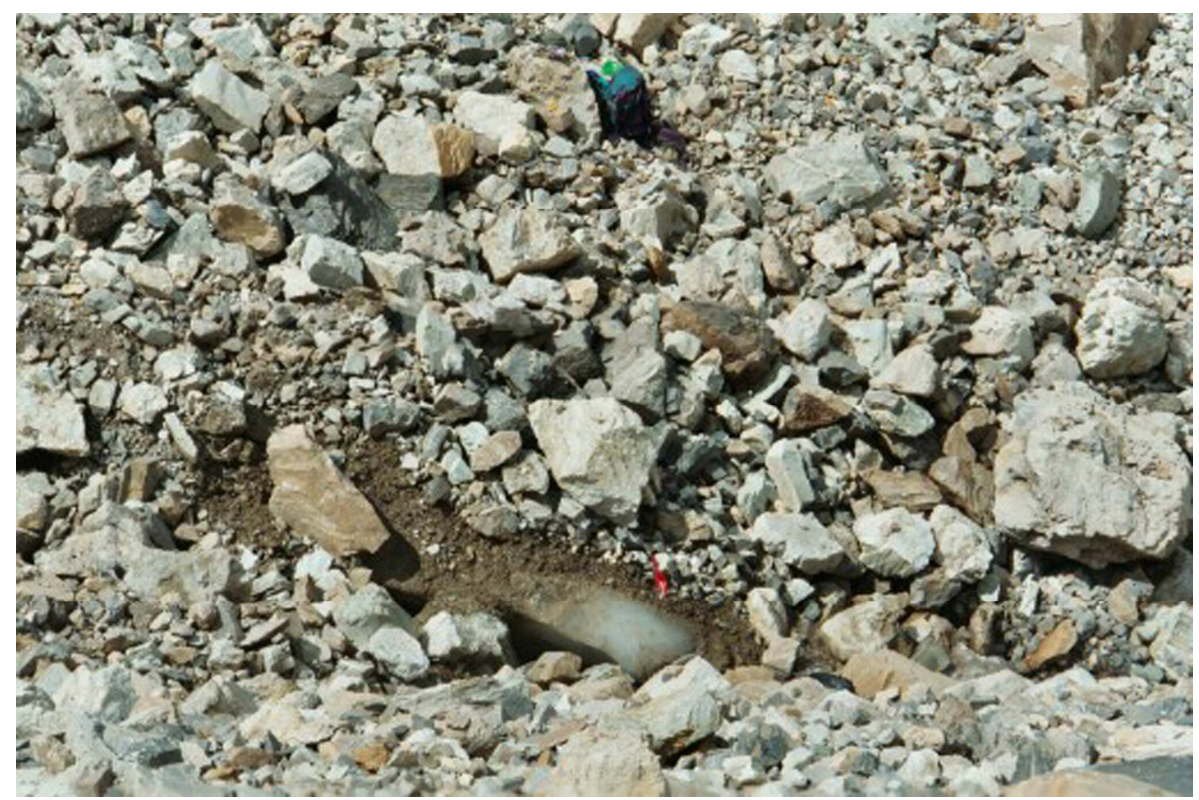

Fig. 4. Natural exposure of massive ice as observed on the field during the summer of 2003. The backpack and the trowel give the scale.

\section{TCD}

5, 3597-3626, 2011

Glacier ice in rock glaciers

S. Monnier et al.

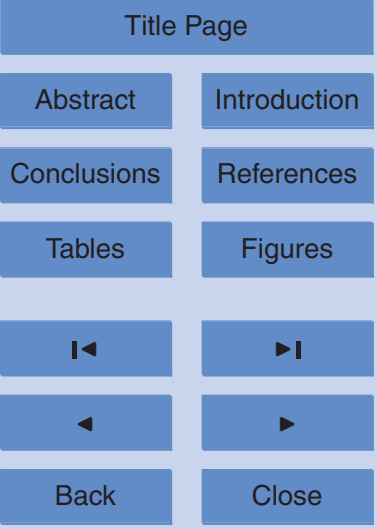

Full Screen / Esc

Printer-friendly Version

Interactive Discussion 

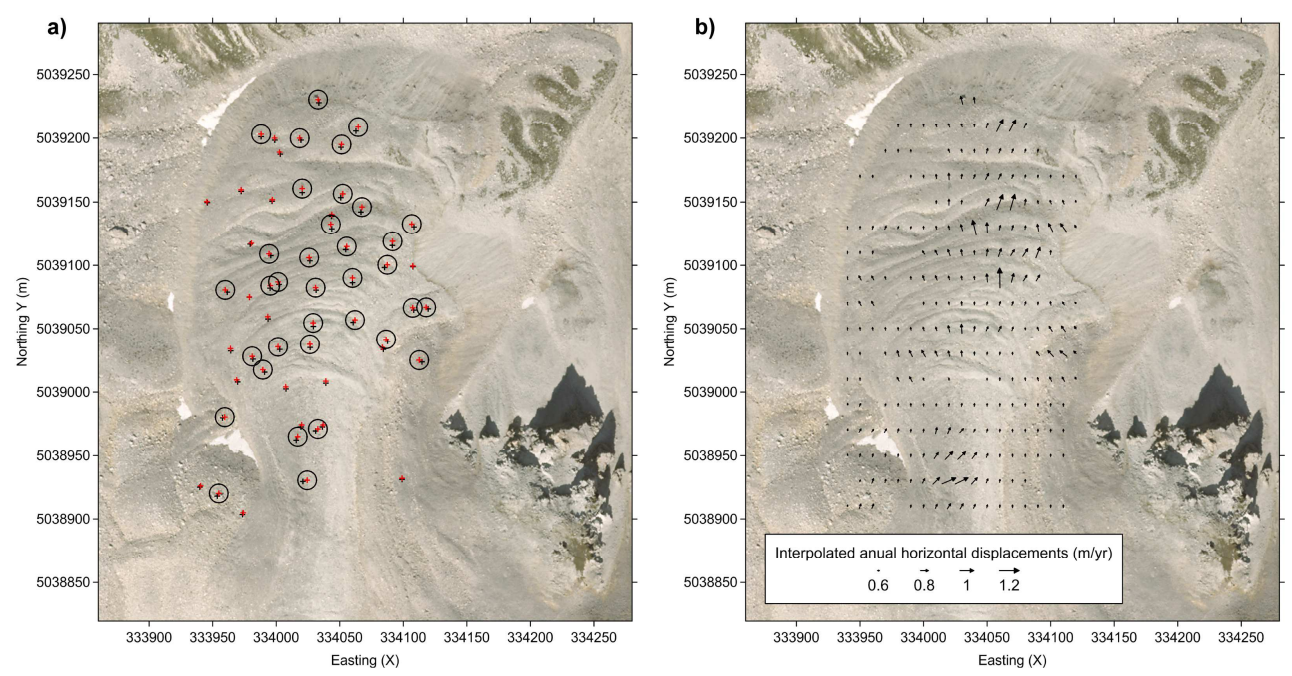

Fig. 5. (a) Horizontal displacements of boulders between 2006 (black crosses) and 2009 (red crosses). Displacements over the position incertitude (pixel resolution + orthorectification error $=1.8 \mathrm{~m}$ ) are surrounded by a circle. (b) Interpolated vectors of horizontal displacement between 2006 and 2009.

\section{TCD}

5, 3597-3626, 2011

Glacier ice in rock glaciers

S. Monnier et al.

Title Page

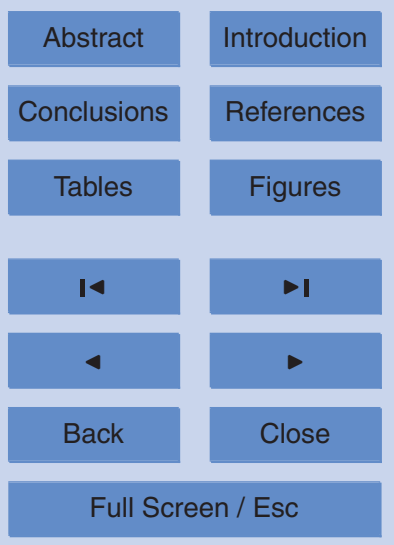

Printer-friendly Version

Interactive Discussion 

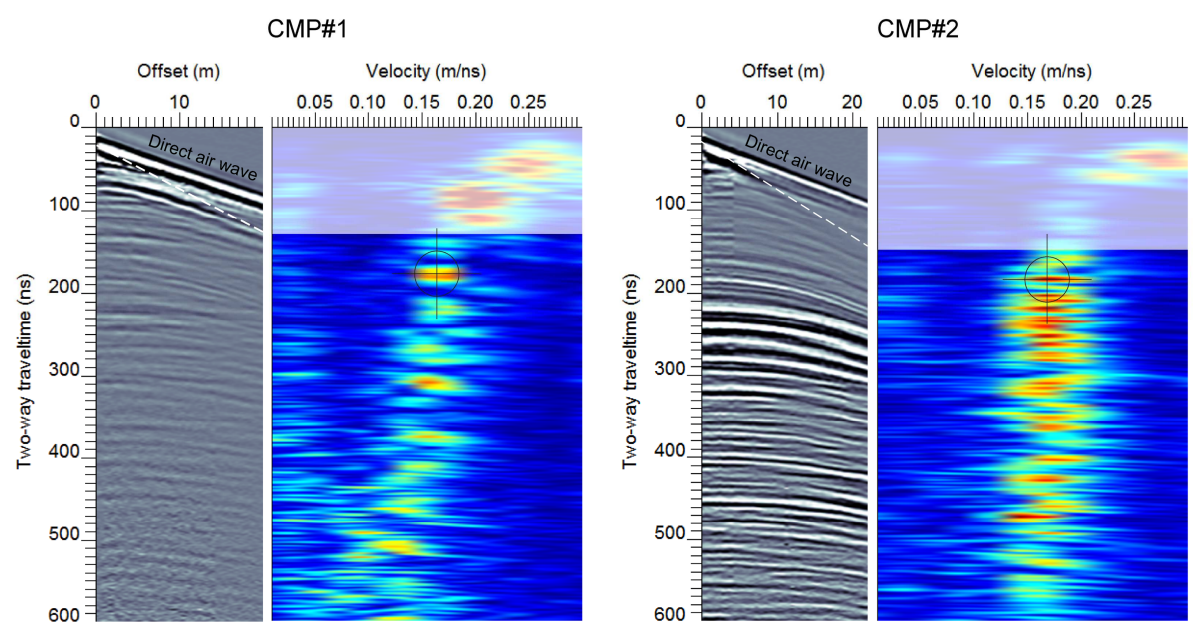

\section{Glacier ice in rock glaciers}

\section{S. Monnier et al.}

Fig. 6. Result of the CMP analyses. The direct air wave and the ground wave (white dashed line) are well identifiable. The first $130-150 \mathrm{~ns}$ are neglected to avoid errors in the velocity determination that could be caused by the overlapping of the direct air wave and the ground wave. The colour plots indicate the amplitudes deriving from the semblance analysis that measure the adequacy of velocity for horizontal correction of hyperbolic reflectors in the CMP radargram: blue (low amplitude) to red (high amplitude). The targets indicate the high amplitude zones used for determination of the radar wave velocity in the shallow massive ice. 

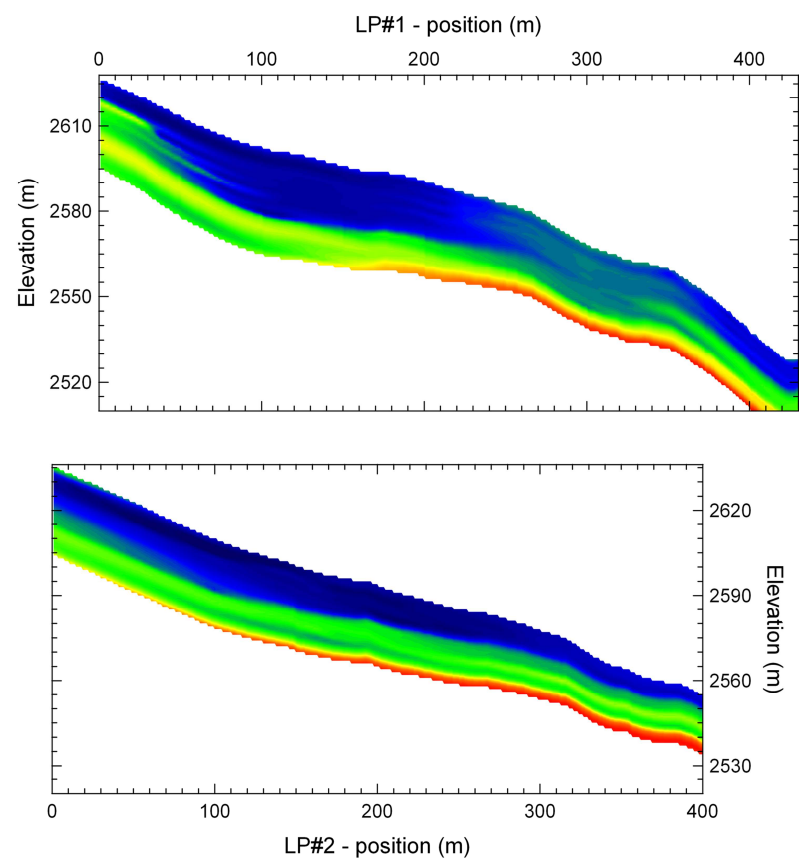

TCD

5, 3597-3626, 2011

\section{Glacier ice in rock} glaciers

\section{S. Monnier et al.}

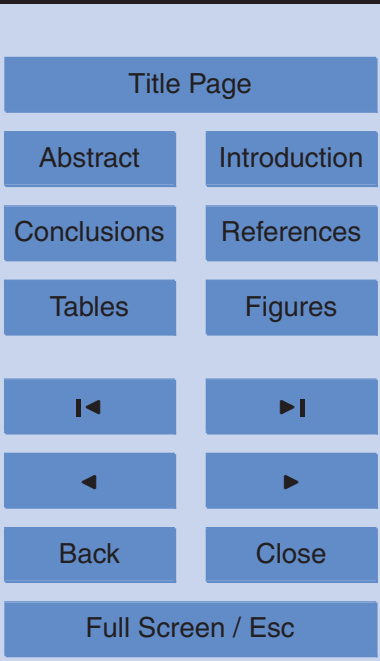

\section{Radar wave velocity (m/ns)}

Fig. 7. 2-D models of the (interval) radar wave velocity along the two longitudinal profiles. The offset in position between the two profiles is integrated in the figure.

Printer-friendly Version

Interactive Discussion

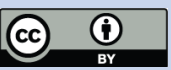




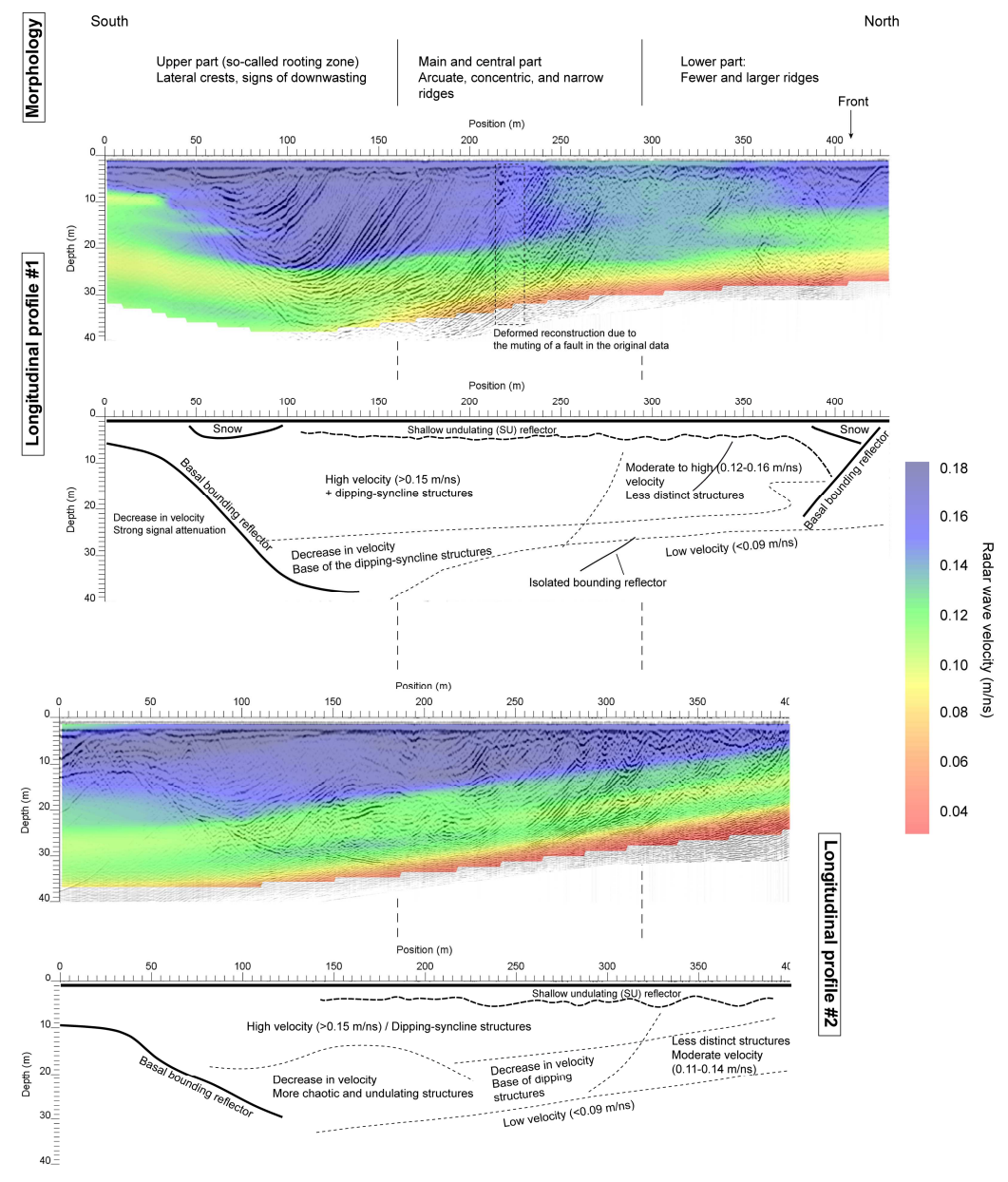

TCD

5, 3597-3626, 2011

\section{Glacier ice in rock} glaciers

\section{S. Monnier et al.}

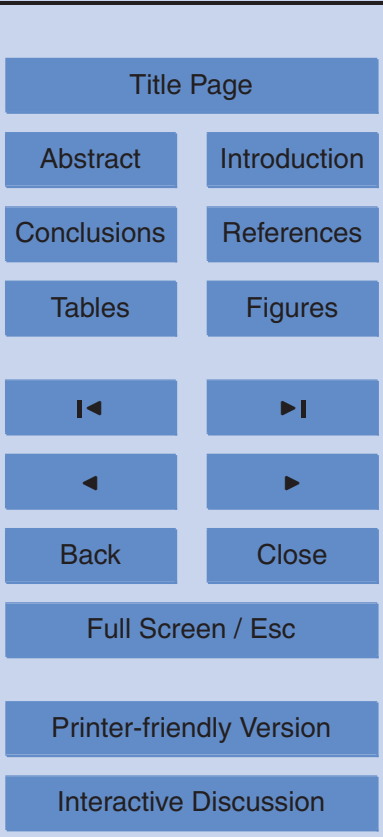

Fig. 8. Integrated representation of the migrated stratigraphy and of the 2-D velocity models along the two longitudinal profiles. The offset in position between the two profiles is integrated in the figure. 


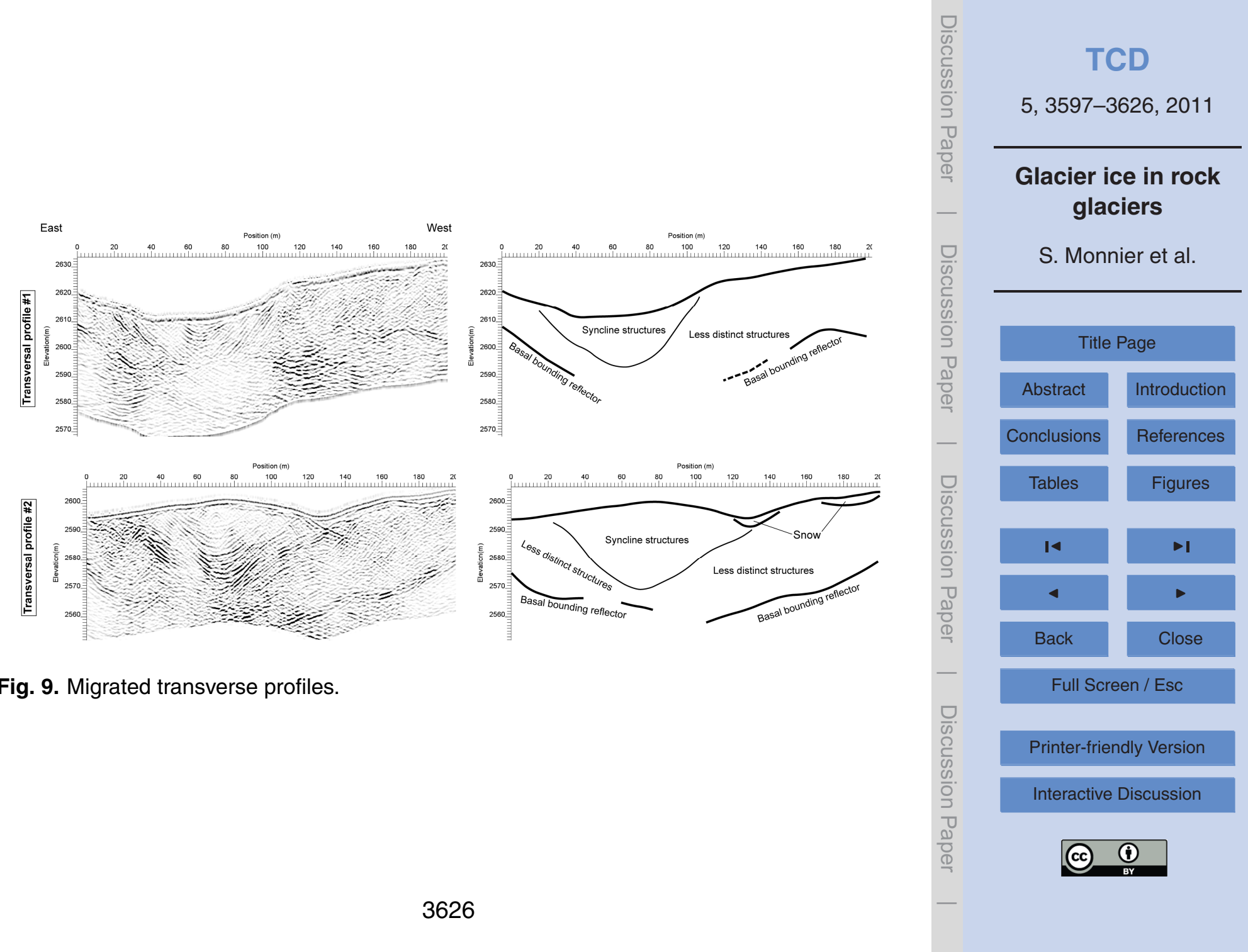

